\title{
The Critical Mission of Muslim Economist
}

\author{
By: Asad Zaman*
}

\begin{abstract}
Abstrak
Persoalan mendasar yang dihadapi para ekonom muslim dewasa ini adalah apakah mereka siap menghadapi tantangan untuk membangun suatu sistem Islami yang ideal? Bisakah mereka menawarkan suatu konsep tentang tata cara mengislamkan sistem kenegaraannya? Menghadapi persoalan-persoalan tersebut, penulis artikel ini mempunyai kehawatiran tentang ketidakmampuan dan ketidaksiapan kaum muslimin untuk memberikan jawabannya karena kenyataannya betapa perbedaan pendapat di kalangan kaum muslimin amat tajam, dan hampir sulit untuk mencapai suatu konsensus termasuk dalam bidang ekonomi Islam dan gambaran yang jelas tentang sistem ekonomi Islam dan sekaligus prakteknya. Dengan demikian, problema ekonomi Islam mencakup sisi konsep dasar sistem ekonomi dan sekaligus implementasi nyata dari konsep dasar tersebut.
\end{abstract}

Keywords: muslim economist, Islamic system, concept and critical mission.

\section{Introduction}

Dr. Iqbal has given a clear picture of the accomplishments of these last. I would like to match the achievements against the goal: what are we trying to accomplish as Muslim economists? The mission that we are trying to fulfill started as a historical necessity. When Muslims struggled for freedom from colonization all over the world, it was necessary for them to take a stand on how they would organize the country after liberation. One of the important elements in the demand for freedom was that idea that Muslims would be free to practice their religion, which offered a complete social, political and economic system. Muslim leaders all over the world appealed to Muslims to participate in the struggles for liberation in the name of Islam. Our vision was that the Islamic system would eliminate oppression and injustice, provide equal opportunities for all, eliminate poverty, and in general be far superior to capitalism and communism.

The crucial question that faces us as Muslim economists is: are we ready for the challenge of constructing an ideal Islamic system? Can we give appropriate

* International Institute of Islamic Economics International Islamic University Islamabad, Pakistan. Email: asadzaman@alum.mit.edu 
advice to governments which wish to Islamize their systems? My fear is that we are currently unable to do so. The diversity of opinions among Muslim economists is extreme. We do not have any agreement on even the definition of "Islamic Economics", and no clear model of what an ideal Islamic economic system would look like in concrete and practical terms. To get a clear idea of how critical the problem we face is, it is sobering to look at the ideas of a critic of Islamic economics. Sohrab Behdad ${ }^{1}$ writes that:

Similar to other utopias, the Islamic ideal world would be a just and humane society, without the exploitation, domination, alienation, and other social ills that have afflicted the contemporary capitalist and socialist societies. [However, in practice, the Iranian revolution did not succeed in creating such a system.] Frustrated by conflicts between the Parliament and the Ulema, one of the followers of Khomeini said: "Ten Years after the Islamic Revolution, ... [we] ask you ... to present to the world the unadulterated Muhammadan Islamic view on economics“. In June 1989 Ayatollah Khomeini died, unable to define his version of Islamic economic order. It has become apparent that an Islamic economic system is not capable of presenting a viable social alternative.

He goes on to say that having failed to present any distinctive Islamic system, with any clear advantages over the capitalism, Iran has gone back to follow World Bank and IMF, and abandoned their initial claims that an Islamic system would help the poor and the oppressed, or indeed that there exists a distinct Islamic economic system.

An equally dangerous example for us is the history of how Christians legitimized interest. This is detailed in Jones ${ }^{2}$. After complex maneuvers quite similar to what Muslims are currently engaged in, the public gradually came to realize that there was no difference between "Christian" system and interest, and stopped using complex means to accomplish simple goals. To explain this in the Islamic context, consider the tremendously successful "Sukuk". This is a very complex legal maneuver which basically replicates what a standard Western bond issue does with much greater simplicity. It does not offer any social benefits, or further any Islamic goals of any type. Ultimately, people will ask, why should we go through this complex dance, when exactly the same thing can be done in a much easier way? In general, a group of Muslim economists/fuqaha are working on attempting to replicate Western financial structures by studying loopholes in Islamic laws. If they are successful, we will find ways to legitimize

${ }^{1}$ Sohrab Behdad (1994). "A Disputed Utopia: Islamic Economics in Revolutionary Iran". Comparative Studies in Society and History, Vol. 36, No. 4. (Oct., 1994), pp. 775813.

${ }^{2}$ Norman Jones (1989). God and the Moneylenders: Usury and Law in Early Modern England. (Oxford: Blackwell). 
all Western financial methods. Then we will successfully replicate the Western system within Islamic forms. But this really means that there is no Islamic system as such - obviously an imitation Western system will produce what it currently does: exploitation, injustice and economic misery.

This shows that the task facing us as Islamic economists is very critical. Unless we succeed in providing a genuine alternative to Western models, the idea of Islamic economics will be swept away. All the claims that we made for providing justice and ending exploitation and misery will be shown to be false. Currently, I believe too much effort is being made on forms and laws, and insufficient attention is being paid to the spirit and the heart of the Islamic economic system. After substantial study of the two systems, I have come to the conclusion that the central difference between them is that the western system is based on greed and competition, while the Islamic system is based on generosity and cooperation. The practical problem that faces us, both as Muslims, and as economists, is how to get from here to there? We need to find ways of Islamizing the economy which conform to both the spirit and the form of Islamic law, instead of just the form, which is taking up most of the current efforts of Islamic economists. Before we discuss practical suggestions for this, we pause to contrast the spirit of Islamic and Western financial systems.

\section{Contrast Between East And West:}

Just as political control is a means to establish worship and encourage good deeds:

Q22: 41 (Allah will help) Those who, if We give them power in the land, establish regular prayer and give regular charity, enjoin the right and forbid wrong.

so economic striving is a means to purchase paradise:

Q9: 111 Allah hath bought from the believers their lives and their wealth in return for Paradise.

On the strength of these prescriptions, our visionary leaders promised a just system, which would end exploitation and misery, provide equal economic opportunities to all, end the evils of both capitalism and communism, and provide justice in all dimensions of life, social, political and economic.

These ideals of Islam are in stark contrast to existing social, political and economic systems. Weber ${ }^{3}$ writes that the 'spirit of Capitalism' is the pursuit of wealth as an end in itself, to the point of being 'absolutely irrational.' Keynes, who was an architect of modern economic thought, as well as the global financial institutions (IMF and World Bank), expresses the fundamental ideas behind current Western financial systems very clearly:

\footnotetext{
${ }^{3}(1930$, Chapter 2)
} 
"When the accumulation of wealth is no longer of high social importance, there will be great changes in the code of morals. We shall be able to rid ourselves of many of the pseudo-moral principles which have hag-ridden us for two hundred years, by which we have exalted some of the most distasteful of human qualities into the position of the highest virtues. We shall be able to afford to dare to assess the money-motive at its true value. The love of money as a possession as distinguished from the love of money as a means to the enjoyments and realities of life - will be recognised for what it is, a somewhat disgusting morbidity, one of those semi-criminal, semi-pathological propensities which one hands over with a shudder to the specialists in mental disease... But beware! The time for all this is not yet. For at least another hundred years we must pretend to ourselves and to everyone that fair is foul and foul is fair; for foul is useful and fair is not. Avarice and usury and precaution must be our gods for a little longer still. For only they can lead us out of the tunnel of economic necessity into daylight ". ${ }^{4}$

This Keynesian idea, that first we must become wealthy, then we can afford to be moral - first we must worship the gods of greed and usury, in order to become free of economic necessity - is at the heart of modern western economic systems and thought. This idea is in direct conflict with Islamic teachings. Men were told to be generous and give to others out of whatever they had, and not to strive to become rich so as to be able to be generous. The Quran mentions that the Ansar

Q59: 9 love these who flee unto them for refuge, and find in their breasts no need for that which hath been given them, but prefer (the fugitives) above themselves even though they are themselves poor. And whoso is saved from his own avarice such are they who are successful.

Avarice and greed are condemned, as is the accumulation of wealth:

Q104: 2 [Woe unto him] who amasses wealth and counts it a safeguard:

The West has promoted the idea of greed and acquisitiveness so much that it has come to appear natural, and many have forgotten that it was not always this way. Today, the Muslim student asks us what career to choose so that he can make the most money. In the past, people chose to become doctors so that they could serve mankind; today they go into the profession so that they can make money from the pain and illness of others. Even Muslim economists justify assumptions of selfishness using ayat from the Quran, and argue that Islamic Banks must pursue profits to survive in a competitive world, and cannot afford

${ }^{4}$ From "The Future", Essays in Persuasion (1931) Ch. 5, JMK, CW, IX, pp.329 - 331, Economic Possibilities for our Grandchildren (1930); as quoted in "Keynes and the Ethics of Capitalism" by Robert Skidelsy 
to pursue social goals. The question is: what can we do to change this state of affairs? What are our responsibilities as Muslims and as Muslim economists?

\section{Pathways To Progress}

I believe that as a whole, Muslims have been trying to solve economic problems on the basis of wrong assumptions and misunderstandings regarding the Western economic systems. Just like the wrong medicine administered on the basis of a misdiagnosis will fail to cure the disease, so our attempts at building an Islamic economic system have not been very successful on either a theoretical or a practical front. Three commonly held ideas are, I believe, major errors and obstacles in the path to progress:

1. Western economic theory is, on the whole, a sound way of analyzing economic affairs of men, just like Western Physics provide good theories about natural laws governing the world and Western Engineering provides excellent machines and physical structures.

This idea leads to the concept that Islamic Economics = Western Economics + Zakat - Interest. That is, with minor changes required by Islamic laws, we can adopt Western economic theories and institutions and financial structures to our purposes. My article entitled "A Prelude to Islamic Economics", disputes this idea. I argue that Western economic theory is fundamentally flawed. In general Western social science is based on a false understanding of the nature of human beings; this cannot be compared with Western physical science which deals with particles and laws of nature. This means that Islamic economics cannot be built by making modifications, minor or major, to western economic theories. We must build from scratch, on grounds traced by Muslim pioneers, starting from fundamental principles.

2. Current Western social, political and economic institutions represent a good way of dealing with modern problems. We need to find ways to imitate these within the Islamic legal structure.

In fact, Western institutions in all areas arise out of secular modern ideologies which are fundamentally incompatible with the Islamic worldview. We cannot adopt their institutions into an Islamic framework since their spirit is not compatible with ours. This makes our task doubly difficult, since we cannot go back to our past for solutions either. Modern problems are genuinely new problems, and require new solutions; however, we cannot use Western solutions. We can look to our traditions for guidance and learn about the spirit of an Islamic approach to solutions, but we must devise creative new solutions. I have argued this at length in my paper "Islamic Economics: A Survey of the Literature".

To explain this further, consider the idea of an Islamic Bank. Note that banks have not always existed in the west. Usury was considered a vile enterprise and a flagrant manifestation of unchecked greed; only the despised Jews were 
moneylenders in Medieval Europe. The Bible states that "the love of money is the root of all evil". Gradually, as religious thinking was replaced by secular, the pursuit of wealth for its own sake was legitimized in the West. Bernard Shaw was able to write that "the lack of money is the root of all evil". This led to the Keynesian idea above that only wealthy people can be moral. This led to legitimacy of Banks, whose main purpose is to help people make money. The wealthy are instructed in ways to increase their wealth, and this is the purpose of all western financial institutions.

The pursuit of wealth for its own sake is condemned in Islam. The wealthy are advised to use their wealth to purchase the benefits of the Akhirah. In contrast, Islamic Banks imitate Western Banks in advising clients to increase their wealth. The only difference is that they recommend Halal means of doing so, instead of Haram. In this way, they achieve compliance in form with the Shari'ah, but not in the spirit. Unless we try hard to achieve the spirit, we will fail to achieve an Islamic system. In my article "Islamic Economics: A Survey of the Literature", I have discussed the bare-bone outlines of an alternative financial system which would comply with the spirit of Islamic economic teachings rather than just with the form. Much more effort in this direction is needed than is currently being made.

3. Western methodologies for acquiring knowledge, their pedagogical methods and educational institutions are the best possible, and we must imitate them to make progress.

The Muslims invented the concept of higher education and gave it to the whole world. Goody ${ }^{5}$ has documented how the Muslim universities of Spain were copied by Europe, and how this knowledge was suppressed in the historical accounts ${ }^{6}$. Similarly, in other cultures, education was regarded as a luxury good, to be given only to a special few. Muslims invented the concept of universal education, as well as education for women, and gave it to the whole world; see Shalabi ${ }^{7}$. In the meantime, Reuben ${ }^{8}$ has described how the American universities were forced to abandon the idea that education was meant to develop Press).

${ }^{5}$ Jack Goody (2007). The Theft of History. (Cambridge: Cambridge University

${ }^{6}$ It is amusing to note that the gowns and caps used in graduation ceremonies are not native European costumes - these were borrowed from Muslim graduation ceremonies which involved putting on the headgear of an Imam to symbolize the completion of education. Today, in this, as in many other areas, we are borrowing from the Europeans what they borrowed from us.

${ }^{7}$ Ahmed Shalaby (1954). History of Muslim Education. Ph.D. Thesis Cambridge University. Republished: Beirut, Lebanon: Dar al-Kashaf.

${ }^{8}$ Julie A. Reuben (1996). The Making of the Modern University: Intellectual Transformation and the Marginalization of Morality. (Chicago: University of Chicago Press). 
character, and resulting damage done to higher education. Today, youth in American universities can learn how to create atom bombs, but nothing about the ethics of killing innocents. They can learn how to cut out and replace hearts but nothing about the feelings of love, compassion, and the fear of God that are needed to purify the hearts. There are many aspects of Western methodology, both in teaching and in social science, which are in conflict with Islam. A detailed discussion is given in my article "Islamic Economics: A Survey of the Literature". Here I deal with only one; the idea that a scientist must be a neutral and detached observer. Our methodology is to struggle to change ourselves and others, to bring the world in conformity with the orders of Allah. This struggle is meant to bring about inner spiritual transformation, and bring us closer to God:

Q29: 69 And those who strive in Our (cause), - We will certainly guide them to our Paths: For verily Allah is with those who do right.

The Prophet Muhammad (May Allah shower his peace and blessings upon him) was the best teacher in all of human history; with his example before us, it is shameful to look to other models for education. The effect of his training transformed people who were near savages (burying their daughters alive and killing each other over minor issues) to models of civilized behavior for all time to come. Today this type of training is not available anywhere in the world, including Muslim countries. Because of the general decline in morals, the world is beginning to look like Jahilliya. More than 600 mothers kill their own children in the USA every year, and trillions of dollars of are spent on killing innocents and destroying infrastructure, putting to shame the savagery of earlier times. Our only hope is to re-learn our traditions, which contain complete guidance on how to achieve spiritual transformation. At the core is the idea that all our prayer, and our striving, and our living and our dying should be devoted solely to Allah, the Sustainer of the worlds.

Q13: 11 ... Verily, God does not change men's condition unless they change their inner selves...

God has entrusted this Ummah with the mission to convey his message to all of mankind. Today, with a general decline in morals, character and integrity, this has become an urgent need. Instead of the passive and detached observer role of the Western scientist, we must become passionately engaged in actively solving the problems facing the Ummah.

All praise is for Allah alone; may He guide us all to the right path, and make us among those who sell their lives and wealth for his pleasure.

\section{REFERENCES}

Sohrab Behdad, "A Disputed Utopia: Islamic Economics in Revolutionary Iran", Comparative Studies in Society and History, Vol. 36, No. 4. (Oct., 1994), pp. 775-813. 
Asad Zaman: The Critical Mission ofMuslim Economist ...

Jack Goody (2007). The Theft of History, Cambridge: Cambridge University Press.

Norman Jones (1989). God and the Moneylenders: Usury and Law in Early Modern England. Oxford: Blackwell.

Julie A. Reuben (1996). The Making of the Modern University: Intellectual Transformation and the Marginalization of Morality, Chicago: University of Chicago Press

Ahmed Shalaby (1954). History of Muslim Education. Ph.D. Thesis Cambridge University. Republished: Beirut, Lebanon: Dar al-Kashaf. Urdu translation by M. Hussain Zubairi: Tareekh-e-Taleem o Tarbiyat-e Islamia Lahore: Idara Saqafate Islamiya, 1989.

Asad Zaman (2008). "Prelude to Islamic Economics", 7th International Conference on Islamic Economics, IERC, KAAU, Jeddah, April $1-3,2008$

Asad Zaman (2008). "Islamic Economics: A Survey of the Literature", Religions and Development Working Paper 13, University of Birmingham. 